\title{
Assessment of the mortality rate of some ornamental fish species in Nigeria export trade
}

\author{
Mbawuike, B.C., S.U. Ukaonu, A. B. Williams, Oyebanji, M. O., H. O., Omogoriola, N. \\ Ajuonu, E. O. Oluwajoba, F. C. Olakolu and A.O. Ayorinde
}

\begin{abstract}
107 fish specimen was studied for one month; comprising of 5 families made up of 7 species (table 1). Mortality rate which is estimated as DOA (Death on Arrival) range from 0.9 to 8.4 which is less than the industry standard- 5\%. 37 out of 107 fishes died at the end of experiment (table 2b). Gnathonemus petersii recorded the highest mortality rate of $100 \%$ while Polypterus bichir lapredei and Polypterus ansorgii recorded no mortality at all (table 4). Importers assertion of $100 \%$ DOA is unacceptable for Nigerian ornamental fish exported.
\end{abstract}

Keywords: Assessment, Mortality, Ornamental fish, Nigeria, Export trade,

\section{INTRODUCTION}

The export of ornamental fish in Nigeria is a thriving market which over the years has been faced with issues of fishes being reported dead on arrival (DOA). Members of the Association of Ornamental Fish Farmers and Exporters of Nigeria (AOFFEN), the body solely responsible for the export of ornamental fishes to importing countries such as the USA, France, Germany, Belgium, Sri Lanka, China, Hong Kong, Thailand, South Africa, Indonesia, India, Netherlands, Singapore, Philippine amongst others Mbawuike and Pepple (2003), Areola (2004) have had to live with the problems associated with DOA. As a result, huge loses to the tune of hundreds of thousands of dollars as income in a trade which is globally a multimillion dollar venture is regularly experienced and reported. Koroye (2010 personal com).

Nigeria's indigenous ornamentals have been reported to die sometimes as high as $100 \%$ in transit, Areola (2003). However for their aesthetics, one of the major reasons for which they are sought after, they are exported. Reports of DOA by importers from several importing countries leave much to be desired. It is to this end this work was carried out, to debunk or not to debunk the claims of these importers.

Fish mortality can be as a result of several factors which have been reported to include stress, temperature, lack of food and oxygen, diseases, pollution, wrong handling technique and over crowding. Studies on mortality of fish have been carried out by workers including Paling (1971), Morris (2005), Hemdal (2009) and Ploeg (2005). According to Ploeg (2005), mortality is a topic that is avoided as much as possible, and as little independent scientific information is available, mortality figures are chosen which suit the purpose of those choosing them. As different interest groups rally around figures to their advantage.

\section{MATERIALS AND METHOD}

107 ornamental fishes comprising of five (5) families [Identification was by Olaosebikan and Raji (1998)] were collected from an exporter (Avis Aquarium Supply Ltd) at Ikorodu in Lagos state of Nigeria by 8am. Fish was transported in two (2) gassed polythene bags (GPB) through a distance of $50 \mathrm{~km}$ in commercial vehicles to destination (Akowonjo area of Lagos state). To prevent heating up of water in GPB, each bag was placed in sacks which where properly insulated with news papers. A third bag containing water (for acclimatizing) was also transported. Each bag of fish and water was quarantined with an antibiotic (a capsule each of $250 \mathrm{mg}$ of tetracycline). On arrival at destination (Akowonjo) by $10.25 \mathrm{am}$, fishes were used for decoration at a wedding reception. At the end of the reception $(4.30 \mathrm{pm})$, live fishes were re-bagged without being gassed, and transported to Egbeda area of Lagos state, a distance of $4 \mathrm{~km}$ by car for this study. At Egbeda, each bag of fish was emptied into 2 big plastic basins (30L each) and observed at room temperature $\left(26^{\circ} \mathrm{C}\right)$ for a month to ascertain the rate of fish mortality. No feeding was done during the period of observation. Daily changing of water with chlorine free water (well water) was carried out and there was no further use of antibiotics. Dead fish were removed with a plastic sieve, measured with a ruler, photographed and disposed of. Interactive sessions with some exporters 
of ornamental fish were undertaken, to ascertain their losses in dollar value over time.

\section{RESULT}

Table 1: Types and Numbers of Ornamental fishes

\begin{tabular}{|l|l|l|c|}
\hline \multicolumn{1}{|c|}{ FAMILY } & \multicolumn{1}{|c|}{ NAME } & LOCAL NAME & NUMBER \\
\hline Characidae & Micralestes elongatus & Alestes & 54 \\
\hline Mormyridae & Gnathonemus petersii & Long nose & 2 \\
\hline Notopteridae & Xenomystus nigri & African knife fish & 14 \\
\hline Pantodontidae & Pantodon buchholzi & Butterfly fish & 19 \\
\hline Polypteridae & Polypterus bichir lapredei & Palmas & 1 \\
\hline Polypteridae & Polypterus ansorgii & Palmas & 1 \\
\hline Polypteridae & Erpertoichthys calabaricus & Reed & 16 \\
\hline
\end{tabular}

Total number of ornamental fishes $=107$

Table 2: Daily report of dead fish by species

TYPE OF FISH

\begin{tabular}{|c|c|c|c|c|c|c|c|}
\hline$D A Y$ & M.elongatus & G.petersii & $X$. nigri & P.buchholzi & $\begin{array}{l}\text { P.bichir } \\
\text { lapredei }\end{array}$ & P.ansorgii & E.calabaricus \\
\hline 1 & $6(3.4-5.0 \mathrm{~cm})$ & & & & & & $1(15 \mathrm{~cm})$ \\
\hline 2 & $\begin{array}{l}5 \\
5.0 \mathrm{~cm})\end{array}$ & $\begin{array}{l}2(15.0 \mathrm{~cm}) \\
(17.5 \mathrm{~cm})\end{array}$ & & $1(8.3 \mathrm{~cm})$ & & & $1(18.1 \mathrm{~cm})$ \\
\hline 3 & & & & & & & $1(23.2 \mathrm{~cm})$ \\
\hline \multicolumn{8}{|r|}{ - } \\
\hline \multicolumn{8}{|l|}{5} \\
\hline 6 & $1(8.4 \mathrm{~cm})$ & & & & & & \\
\hline 7 & $5(3.8-4.6 \mathrm{~cm})$ & & & & & & \\
\hline 8 & & & & & & & $2(22.6,24.0 \mathrm{~cm})$ \\
\hline 9 & & & & $1(6.3 \mathrm{~cm})$ & & & $1(29.4 \mathrm{~cm})$ \\
\hline \multicolumn{8}{|l|}{10} \\
\hline 11 & $1(5.8 \mathrm{~cm})$ & & & & & & \\
\hline 12 & $1(5.7 \mathrm{~cm})$ & & & & & & \\
\hline 13 & $3(5.3-5.4 \mathrm{~cm})$ & & & & & & \\
\hline \multicolumn{8}{|c|}{ (10 } \\
\hline 15 & $2(6.0,6.0 \mathrm{~cm})$ & & & & & & \\
\hline \multicolumn{8}{|l|}{16} \\
\hline \multicolumn{8}{|l|}{17} \\
\hline \multicolumn{8}{|l|}{18} \\
\hline 19 & & & $1(8.9 \mathrm{~cm})$ & & & & \\
\hline \multicolumn{8}{|l|}{20} \\
\hline \multicolumn{8}{|l|}{21} \\
\hline \multicolumn{8}{|l|}{22} \\
\hline \multicolumn{8}{|l|}{23} \\
\hline \multicolumn{8}{|l|}{24} \\
\hline \multicolumn{8}{|l|}{25} \\
\hline \multicolumn{8}{|l|}{26} \\
\hline \multicolumn{8}{|l|}{27} \\
\hline \multicolumn{8}{|l|}{28} \\
\hline 29 & & & $\mathrm{I}(9.8 \mathrm{~cm})$ & & & & \\
\hline 30 & & & $\mathrm{I}(8.9 \mathrm{~cm})$ & & & & \\
\hline
\end{tabular}


Am. J. Soc. Mgmt. Sci., 2011, 2(3): 325-328

Table $2 b$ : Daily death of fish

\begin{tabular}{|l|l|l|l|l|l|l|l|l|l|l|l|l|l|l|}
\hline DAY & 1 & 2 & 3 & 6 & 7 & 8 & 9 & 11 & 12 & 13 & 15 & 19 & 29 & 30 \\
\hline $\begin{array}{l}\text { No.of } \\
\text { dead Fish }\end{array}$ & 7 & 9 & 1 & 1 & 5 & 2 & 2 & 1 & 1 & 3 & 2 & 1 & 1 & 1 \\
\hline $\begin{array}{l}\% \text { rate of } \\
\text { mortality }\end{array}$ & 6.5 & 8.4 & 0.9 & 0.9 & 4.7 & 1.9 & 1.9 & 0.9 & 0.9 & 2.8 & 1.9 & 0.9 & 0.9 & 0.9 \\
\hline
\end{tabular}

Total deaths $=37$ fishes

Total no. of fish $=107$

Table 3: Price of Ornamental fishes

\begin{tabular}{|c|c|c|}
\hline LOCAL NAME & QUANTITY PER BOX & UNIT PRICE(USD) \\
\hline Palmas & $20-40$ & $3-10$ \\
\hline Alestes & 150 & 1 \\
\hline Knife fish & 200 & 0.5 \\
\hline Long nose & 100 & 0.8 \\
\hline Reed & 200 & 0.4 \\
\hline Butterfly & 200 & 0.35 \\
\hline
\end{tabular}

Adopted from 2010 Customer price list of Avis Aquarium Supply Ltd

Table 4: Mortality Assessment

\begin{tabular}{|c|c|c|c|c|c|c|}
\hline 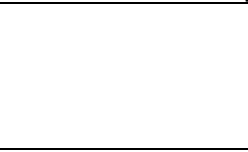 & $\begin{array}{l}\text { No. of fish at } \\
\text { start of } \\
\text { observation }\end{array}$ & $\begin{array}{l}\text { No. of fish } \\
\text { dead at } \\
\text { ending of } \\
\text { observation }\end{array}$ & $\begin{array}{l}\% \text { Mortality at } \\
\text { end of } \\
\text { observation }\end{array}$ & $\begin{array}{l}\text { No. of fish } \\
\text { alive after } \\
\text { observation }\end{array}$ & \% Alive & $\begin{array}{l}\text { Total \% } \\
\text { Mortality }\end{array}$ \\
\hline M. elongatus & 54 & 24 & 44.4 & 30 & 55.6 & 22.4 \\
\hline G. petersii & 2 & 2 & 100 & Nil & Nil & 1.9 \\
\hline$X$. nigri & 14 & 3 & 21.4 & 11 & 78.6 & 2.8 \\
\hline P. buchholzi & 19 & 2 & 10.5 & 17 & 89.5 & 1.9 \\
\hline P. bichir lapredei & 1 & Nil & Nil & 1 & 100 & 0 \\
\hline$P$. ansorgii & 1 & Nil & Nil & 1 & 100 & 0 \\
\hline E. calabaricus & 16 & 6 & 37.5 & 10 & 62.5 & 5.6 \\
\hline Total & 107 & 37 & 34.6 & 70 & 65.4 & 34.6 \\
\hline
\end{tabular}

\section{DISCUSSION/ CONCLUSION}

The packaging and transportation of ornamental fishes in Nigeria involve methods similar to those described by Lim et al (2003). Transit time in Nigeria is 48hrs on the average with report of an alleged DOA of up to $100 \%$ on some occasions, Koroye (personal com.).This allegation though tough on the industry in Nigeria, has not discouraged exporters from exporting ornamental fish, principally because customers from importing countries are disbelieved, and indigenous species are of great demand. Aside from $M$. elongatus and E.calabaricus which exceeded the industry's permitted optimum mortality rate of $5 \%$, the other five groups of fishes were below the standard (Table 4).

Using Lims et al (2003) DA7 (Death after 7 days) theory, average \% rate of mortality is 3.06 (Table2b). This is still below the recommended industry's optimum standard of 5\%. Since fishes were not fed, though daily change of water was carried out, the environment created was to simulate as much as possible that in which transportation takes place where fish are not fed and there is sufficient oxygen. It is therefore asserted that the rate of mortality ascribed to fishes exported from Nigeria by importers is unrealistic. 
According to Ploeg (2005), as a practical result, the reported DOA includes those mortalities on arrival, as well as the mortalities occurring during the first day. Hence importers must claim DOA 24 hours after arrival. Be that as it may, the alleged mortality rate by importers is still unrealistic.

Mortality in every fish type occurred excluding the Polypterus spp.: Hardiness of fish in descending order is from Polypterus spp, Xenomystus nigri, Pantodon buchholzi, Erpetoichthys calabaricus, Micralestes elongatus and Gnathonemus petersii.

The initial death of fish can be attributed to the stress and shocks encountered in the course of transportation over a long distance in hot weather, Nigeria being a tropical country. Subsequent deaths could be a result of the daily change of water, not allowing for the bacterial build up that is necessary for fish stability in captivity.

Though Nigerian ornamentals are wild caught, it is recommended as observed by Lims et al (2003) that since it is assumed that the primary cause of postshipment mortality is partly associated with the low stress resistance of fish, the use of stress resistance enhancement techniques before transportation process be adopted to reduce post-shipment mortality of fish.

To this end, the addition of salt to the recovery water to enhance the stress resistance of the fish is effective in reducing post-shipment mortality. Also, as suggested by (Lim et al, 2003), quality enhancement through health prophylaxis to eradicate parasites would significantly improve the cumulative mortality of ornamental fish at 7 days post shipment.

A promising solution lies also in the use of anesthetics to lower the mortality rate and enhance the stress resistance of ornamental fish.

\section{REFERENCE}

Areola, F. O. (2003). Trends in Live Fish Export Activities in Nigeria: 1996-2000. Proc.of the Fisheries Soc. of Nigeria (FISON) Conf. 2003. pp206-211

Areola, F. O. (2004). Export Potential of Ornamental Live Fishes in Nigeria. Proc. of The fisheries Soc. of Nigeria (FISON) Conf. 2004.pp589-596

Hemdal, J. (2009) Aquarium Fish: Mortality Rates of Fishes in Captivity.Retrieved February2 2011 from http://www.advancedaquarist.com/2009/12/fish2

Koroye, E., (2010) Avis Aquarium Supply (Nig) Ltd

Lim L. , Dhert P. and Sorgeloos P. (2003) Blackwell Publishing Ltd. Aquaculture Research 34, 923-935

Mbawuike B. C. and Pepple P. C. G (2003): Inventory of locally available Ornamental Fish species in Nigerian export trade. Journal of Sustainable Tropical Agricultural Research (JOSTAR) No.403, pp 1-7

Morris, J. (2005). Causes and Solutions of Frequent Aquarium Fish Deaths. Retrieved

February 2, 2011 from

http://ezinearticles.com/?Causes-and-Solutions -of-Frequent-Aquarium-Fish-Deaths\&id=88157

Olaosebikan B.D and Raji (1998) A.: Field Guide to Nigerian Freshwater Fishes. Federal College of Freshwater Fisheries Technology, New Bussa, Nigeria. Pg 106

Paling, J.E.(1971): Causes of mortality. In Methods for Assessment of Fish Production in Fresh Waters, pp.249-258(Ed. W. E. Ricker), IB Handbook No. 3, $2^{\text {nd }}$ Ed. Blackwell Scientific Publication 348pp 255

Ploeg, A. (2005). Facts on Mortality with Shipments of Ornamental Fish. Retrieved

February 2, 2011 from http://www.Ornamental-fishint.org/files/ mortality 